CHRISTY EMILIO IOANNIDOU

The Association of Historical Studies

KORYVANTES

Athens, Greece

E-mail:perialos1@gmail.com
Received: November $14^{\text {th }} 2020$

Accepted: December $10^{\text {th }} 2020$

Original research article

904:614.81"652"(38)

904:316.624"652"(38)

904:656.61"652"(38)

COBISS.SR-ID 29179913

https://doi.org/10.18485/arhe_apn.2020.16.1

\title{
THE BLACK VERSION OF WATER AND UNDERWATER ACTIVITY DROWNING, TORTURE, AND EXECUTIONS BELOW THE SEA IN ANCIENT GREECE DURING THE ARCHAIC AND CLASSICAL PERIODS (SEVENTH TO FOURTH CENTURIES BC)
}

\begin{abstract}
Water and underwater activity was not always a fascinating aquatic experience. There have been cases where people suffered, were tortured, and ended their lives below the sea. Beyond accidental drowning cases, the sea became a grave for murderers, mutineers, impious, and piracy victims as well.

The aim of the present paper is firstly to shed light on cases where drowning was also used as an act of violence and execution in ancient Greece, and secondly to open space for the further study and research of data which have remained obscure.
\end{abstract}

\section{KEYWORDS: DROWNING, EXECUTIONS BELOW THE SEA.}

The existence of categories of divers and the anxiety to discover an early breathing apparatus suggests that the issue of diving and underwater activity was quite topical in classical times (Ioannidou, 2014[b]). In ancient Greek texts, a treasury of words was created for those engaged in diving, depending on the skills they had or the diving depths they were approaching. For example, there are at at least four terms describing divers acting

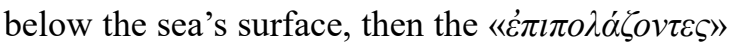
(epipolázontes) who were actually swimming or keeping a position closer to the surface, possibly looking deep down in order to observe the sea-

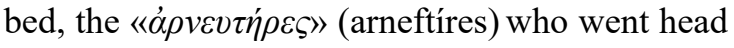
first into water from a high point like modern divers from a diving board, and plenty of names and terms for those who fished under water (Ioannidou, 2014[b], 2012).

Last but not least, in a distinguished category, are included divers who are considered, in mod- ern meaning, to be the first underwater demolition teams, who aimed at underwater tasks in order to sabotage enemy ships (Ioannidou, 2014[b]; Hdt. 8.8; Thuc. 4. 26; Arr. An. 2. 2.21.)

Quite apart from these types of diving, there have also been cases which prove that this fascinating aquatic exercise had simultaneously a 'dark' version. Drowning, even if considered as accidental human immersion, accounts for a long list of deaths in both mythology and ancient history. A great effort to record all the names and references $(n=40,000)$ in a database of ancient and mythological Greek literature ${ }^{1}$ gives us a number of incidents: $\mathrm{n}=37,17$ males $(45.94 \%), 6$ females $(16,22 \%)$, and 14 reports of multiple casualties (37,84\%).

Taking into consideration that cases of mythology are beyond the scope of this paper, there are

1 Devouros, K.D. (2007). [Ancient-cognitional encyclopedia]. Unpublished raw data. See also: Avramidis, S. 2009:422. 


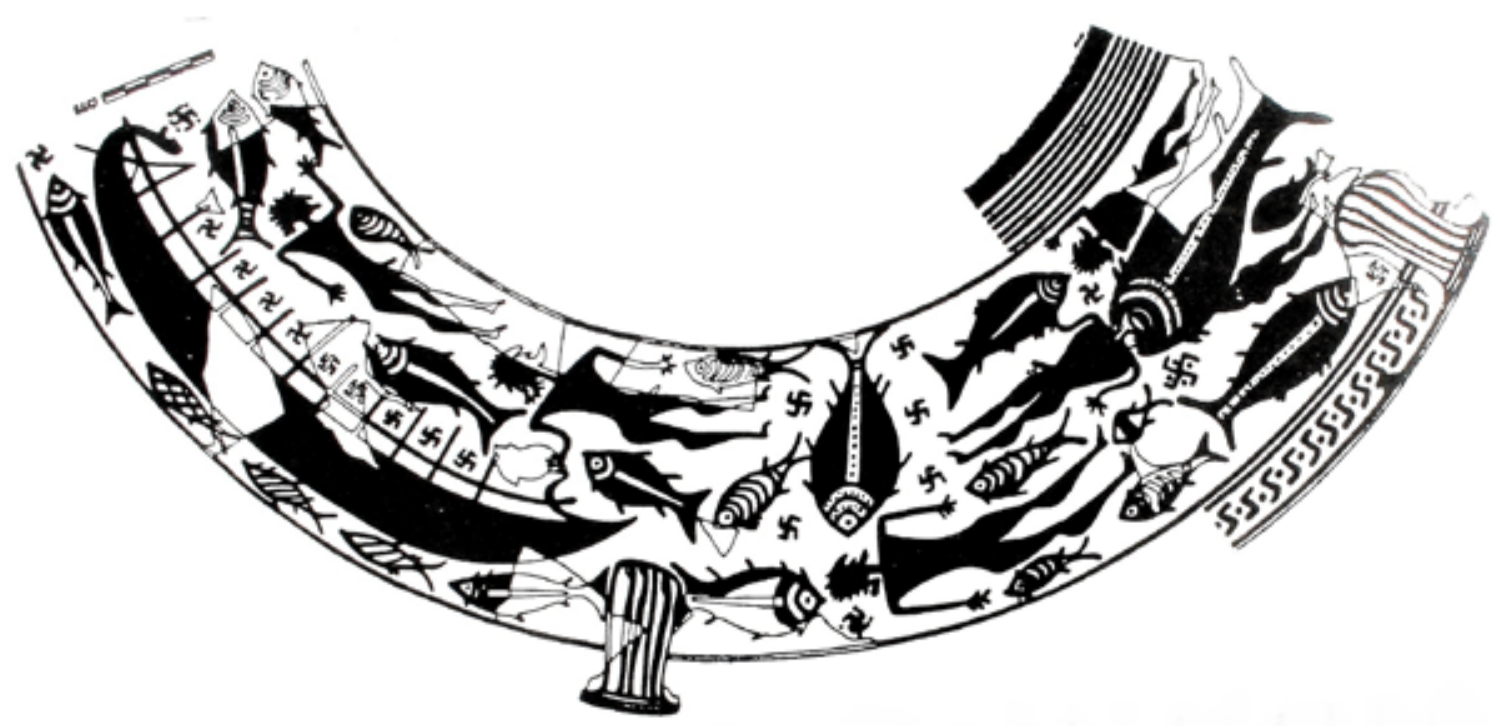

Fig. 1 Late Geometric krater from Pithekoussai, inv. 168813,

(After Stoop, ANTIQUITY AND SURVIVAL 1, 1955/56, 267) in Basch, 1987: p.188.

plenty of cases of accidental incidents of drown-

ing in history, although we can only imagine how many more cases remain unknown. A large number of people who perished in naval battles or seagoing merchant vessels are mentioned. During the naval battle of Salamis, for example, many Persians drowned in the sea because they didn't know how to swim (Hdt. 8.89). The sinking of a cargo ship near the port of Bosphorus (fourth century BC) is, among others, a fact not commonly known. The ship was already overloaded, having an additional deck-load of one thousand hides, which proved to be the cause of the loss. More than thirty people perished besides the cargo (Dem. 34.10). Plenty of similar cases are mentioned in ancient texts. A cruel scene of a capsized ship and drowning men (Fig 1) is depicted on the well-known Late Geometric krater (end of eighth century BC) from Pithekoussai. The painter managed to present in a very brutal but realistic way how an enormous fish ate the head of one of the crewmembers. It's not difficult to imagine how many shipwrecks occurred in ancient Greek history, in open sea, and how many people were eaten by fish and other sea creatures without these cases having ever been recorded.

Individual cases of accidental drowning ex- ist too. Hegestratos (340 BC) was trying to find his tender boat when he jumped out of the ship, but because it was night he could not see it and drowned (Dem.32.6). The death of Greek Socratic philosopher, Euclid of Megara, may appear astonishing: as he was swimming in the Alpheus river, the point of a reed ran into him, causing injury and death (D. L. 2.10.109). Quintus Curtius describes the drowning of Hector (334 BC), son of Parmenion and brother of Philotas and Nicanor. Hector was embarked on a small craft which was overloaded. The craft sank with all hands. Hector struggled for a long time with the river as it was too difficult for him to swim with his drenched clothes and his sandals tightly fastened to his feet. Tired and terrified enough, he tried to ease his breathing but he eventually died (Curt. 4.8.7-9).

The foregoing could be examined more; nevertheless we may speculate on cases where activities in an aquatic environment took place as a type of execution.

In ancient Greek texts, generally, the meaning of death in the sea is describing by the verb

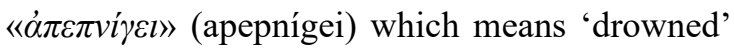
or «d் $\pi \omega \lambda \dot{\varepsilon} \sigma \theta \eta »$ (apolésthi) which means 'perished'. But these verbs describe the outcome of the drowning and not the process or manner of 


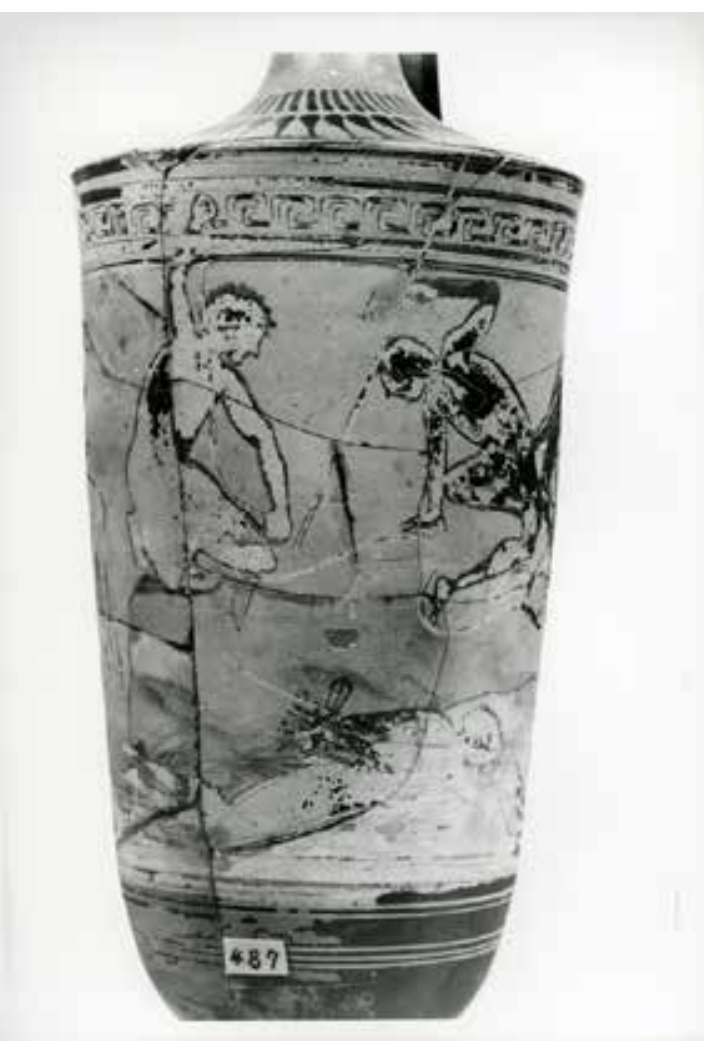

Figs. 2 Lecythos from Attica (480-470 BC).

Credit line: National Archaeological Museum, Athens, photo: K. Konstandopoulos Copyright (C) Hellenic Ministry of Culture and Sports/Archaeological Receipts Fund.

how a person ended up dying in the sea. The word

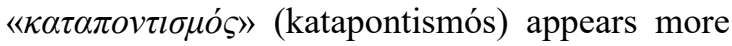
specifically ; it has the meaning of dropping someone from a high point to the ground or to the sea,

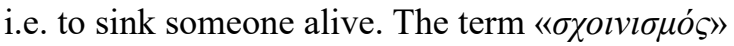
$\left(\right.$ schinismós $=$ the strappado $^{2}$, which appears much later, means to tie someone with rope and drop him to the ground or to the sea.

Beginning with the first case, the act of throwing a person into the sea alive, Herodotus offers a great example of the first action of human jettison. Xerxes King of Persia, was on board but weather conditions were rough and the boat, full of the King's soldiers, was in danger of being swamped. In order to lighten the boat and save their King, many of the soldiers threw themselves into the sea (Hdt. 8.118).

2 Tratto di corda (Italian), estrapade (French), garrucha (Spanish).

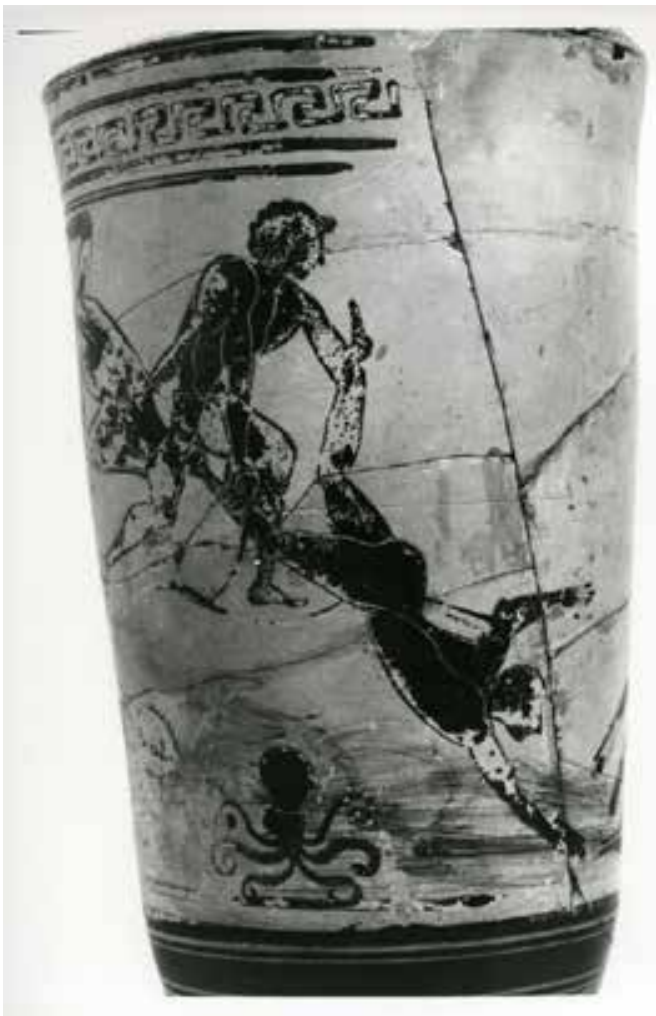

Figs. 3 Lecythos from Attica (480-470 BC).

Credit line: National Archaeological Museum, Athens, photo: K. Konstandopoulos Copyright (C) Hellenic Ministry of Culture and Sports/Archaeological Receipts Fund.

An ideal example of diving as an execution for crimes appears in a text of Plutarch, in which it is written that the murderers of Hesiod were sunk alive (Plut. Septem. 162e). Drowning was also a sentence of death for persons guilty of mutiny. Alexander the Great convicted the mutineers among his soldiers to drowning in the river (Curt. 10.4. 2-3).

Persons who committed sacred crimes faced the same punishment, too. No less than three thousand Phocians were taken captives by Phillip II of Macedon and thrown into the sea as temple-robbers (Diod. 16.35.6).

The revelation of sacred knowledge of ancient mysteries or of particular set of philosophical theories and beliefs was also a crime. Iamblichus states that the Pythagorean philosopher Hippasus (fifth century BC) was the first to publish and describe the sphere from the twelve pentagons. For his impiety he perished at sea but he nevertheless 


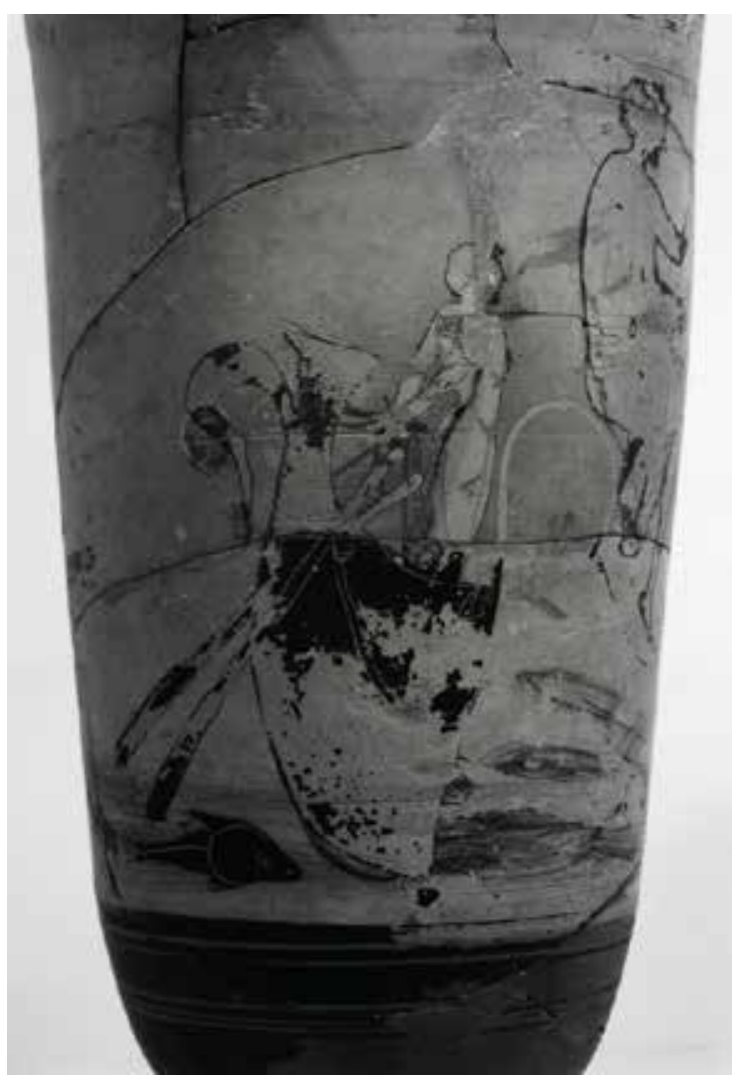

Figs. 4 Lecythos from Attica (480-470 BC).

Credit line: National Archaeological Museum, Athens, photo: K. Konstandopoulos Copyright (C) Hellenic Ministry of Culture and Sports/Archaeological Receipts Fund.

received credit for the discovery (Iam. VP 18.88).

Cases of death in the water which occurred as war crimes should not be put aside, for example, during the naval battle of Sybota (433BC). After the rout of the Corcyraeans, the Corinthians turned their attention to the men who were in the sea instead of taking in tow and hauling off the hulls of the ships which had been disabled. Corinthians, cruising through the shipwrecked people, killed them one by one, even their own friends, without being able to determine who were conquering and who were being conquered (Thuc. 1.50).

During the Peloponnesian War, the Athenian general Filoklis captured two triremes: one from Corinth and one from the island of Andros, while he threw the crews overboard (Xen. Hell. 2.1.31). Parenthetically, in the source text

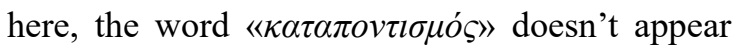

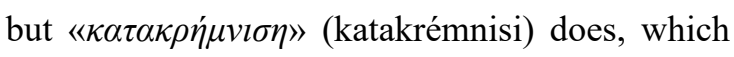
sometimes may confuse researchers as it is leave an explanation of the action of throwing somebody headlong down to the land and not to the

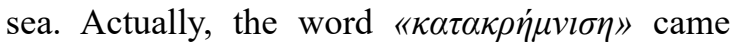

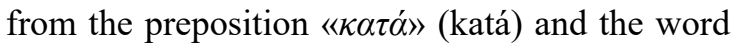

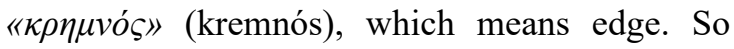

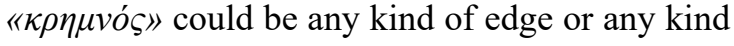
of a point, even if down from this point there is

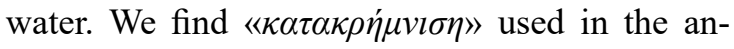
cient texts in various ways, for example from a tower (Diod. 4.31.3), from a horse (Plb. 3.116.12; Xen. Cyrop. 1.4.7. etc.) and from a trireme as mentioned above.

In the fifth book of Herodotus there is quite an interesting story of a strange punishment on board that took place in the fifth century BC. The captain of a Myndian ship was passed by the Persians through a thalamian ${ }^{3}$ oarhole. He was placed with his head out of the keel and the rest of his body inside (Hdt. 5.33). This description leaves many questions, as it is not clear if, for example, the head of the captain was out far enough to almost reach sea level. But we can imagine that if the ship was built according to Greek prototypes of the trireme, the thalamian hole could have had a limited distance of $40 \mathrm{~cm}$ from the sea level ${ }^{4}$. Considering that a human head measures approximately $20 \mathrm{~cm}$ in height without the neck and putting a body as vertical as could be, then it could have been possible that the victim, tied in this position, could suffer by being upside down, feeling the waves crashing onto his face and entering the sea water into his nose and mouth.

What really surprises us is that there are no references to strappado in ancient Greek texts, but it is commonly known that this kind of torture was imposed from the times of the Inquisition, and as a naval punishment many centuries later. The

\footnotetext{
3 Its the oarhole of the lowest file of a three-level ancient Greek galley.

4 Coates, J.F., The Trieres, its design and constrauction, "TROPIS I", 1st International Symposium on Ship Construction in Antiquity, Hellenic Institute for the Preservation of Nautical Tradition, (1985), 83.
} 


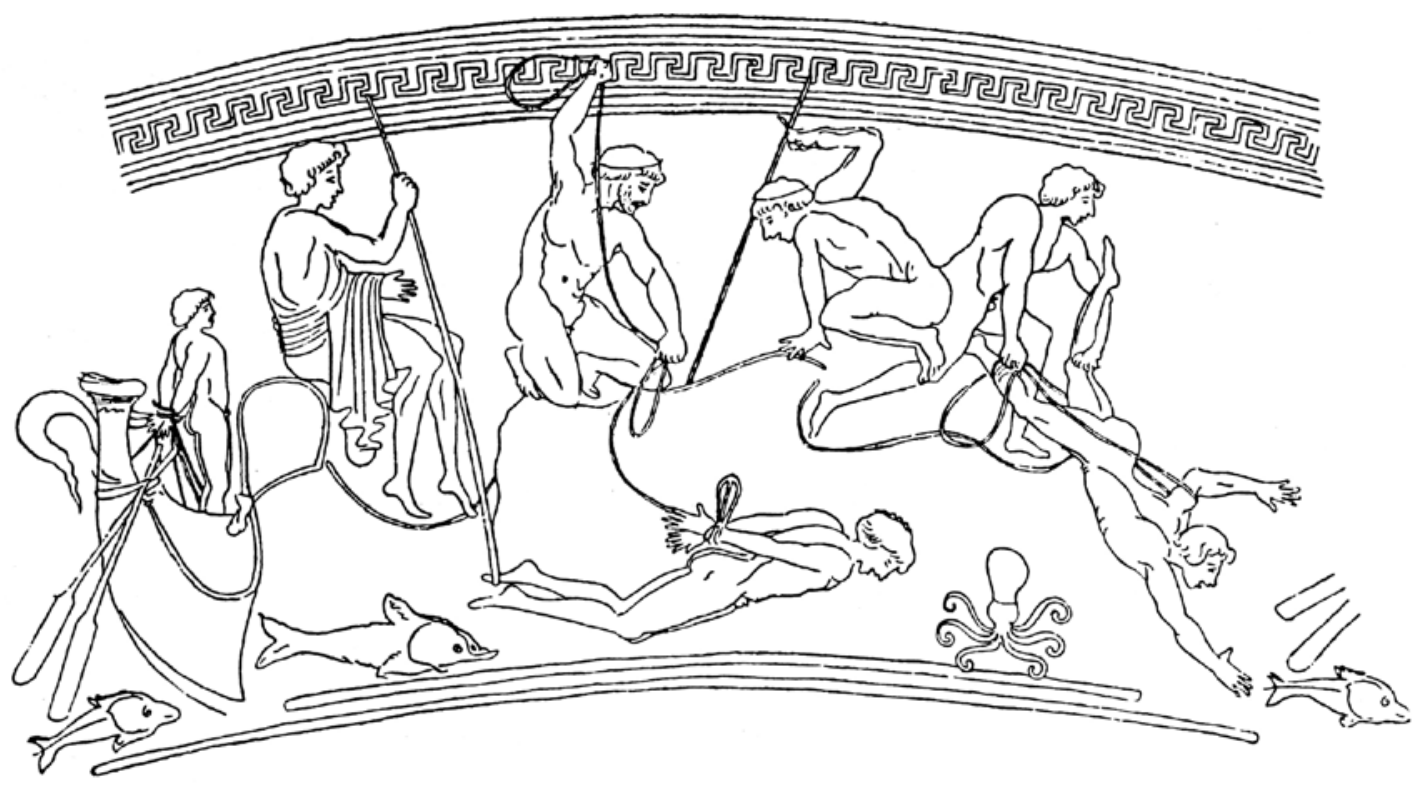

Fig. 5 Lecythos from Attica (480-470 BC) after Ormerod (1924) in Basch, L., Le muse imaginaire de la marine antique, Institute Hellenique pour la Préservation de la Tradition Nautique, (1987), 270.

lack of any concrete information about strappado taking place at sea in the classical period is well illustrated on an Attica lecythos of the fifth century $\mathrm{BC}^{5}$ (figs. 2-5). In this depiction, four men on a ship represent the crew. The figure wearing clothes, perhaps the one who is first in hierarchy, is observing the rest of the crew doing strappado to two men while a third one (perhaps the helmsman) is tied to the prow. The evidence of the tied helmsman guides our thoughts to the assumption that this scene may represent an act of piracy. The scene may also represent another naval punishment, known as keelhauling or keel raking ${ }^{6}$. In an act of keelhauling, a line passed under the ship to snatch the offender off the yard arm, and pull him under the ship to the other side. We can imagine how painful that could have been as the accumulated barnacles on the hull shredded the flesh and most victims couldn't have survived.

In any case, the use of ropes for dropping these

5 Lecythos from Attica (480-470 BC). National Museum of Athens, no 487. Photo from Basch (1987): 270.

6 Was naval punishment on board ships said to have originated with the Dutch but adopted by other navies in the $15^{\text {th }}$ and $16^{\text {th }}$ centuries (Nathaniel Boteler, A dialogic Discourse Concerning Marine Affairs, 1634). two men into the sea corresponds to strappado or to keelhauling, whether this took place as a punishment for an undisciplined crew or as an act of piracy (Ioannidou 2017).

\section{BIBLIOGRAPHY}

\section{Ancient}

Arrian, Anabasis

Curtius, Historiarum Alexandri Magni

Demosthenes, Against Phormio

Demosthenes, Against Zenothemis

Diodorus, Historical Library

Diogenes Laertius, Vitae philosophorum

Herodotus, Histories

Iamblichus, De vita Pythagorae

Polybius, Histories

Plutarch, Septem sapientium convivium

Thucydides, Histories

Xenophon, Cyropaedia

Xenophon, Hellenica 


\section{Contemporary}

Avramidis, S. 2005

World Art on Swimming, International Journal of Aquatic Research and Education 5: 325-360.

Avramidis, S. 2009

Drowning in ancient Greek History and Mythology, International Journal of Aquatic Research and Education 3 (4): 422-431.

Basch, L. 1987

Le muse imaginaire de la marine antique, Athens: Institute Hellenique pour la Préservation de la Tradition Nautique.

Ioannidou, C.E. 2012

Fishing boats and fishermen in ancient Greece, [in Greek] Naval Hellas, Hellenic Maritime Union 946: 38-41.

Ioannidou, C.E. 2014 (a)

Dictionary of Ancient Greek Naval Terminology [In Greek], Athens: Historical Quest.

Ioannidou, C.E. 2014 (b)

Divers in ancient Greece during the late archaic and classical period (6th-4th century BC), $\mathrm{Ar}$ chaeology and Science 10: 111-119.

Ioannidou, C.E. 2017

Piracy in ancient Greece, [In Greek], Athens: Historical Quest.

Frost, F.J. 1968

Scyllias: Diving in antiquity, Greece and Rome 15: $180-185$.

\section{Holloway, R. R. 2006}

The Tomb of the Diver, American Journal of Archaeology 110, n. 3: 365-388.

Quintus, C. R. 1971

History of Alexander, John C. Rolfe (tr.), London:
William Heinemann LTD, Cambridge: Harvard University Press.

Simopoulos, K. 2003

Torture and Power, [in Greek], Athens: Stachy Publishing.

Stamatakos, I. 1999

Ancient Greek language Dictionary [In Greek], Athens: Vivliopromitheftiki.

\section{REZIME \\ CRNA VERZIJA VODE I PODVOD- NIH AKTIVNOSTI: DAVLJENJE, MUČENJA I POGUBLJENJA ISPOD POVRŠINE MORA U ANTIČKOJ GRČKOJ TOKOM ARHAJSKOG I KLASIČNOG PERIODA (VII-IV VEK PRE N. E.)}

\section{KLJUČNE REČI: DAVLJENJE, POGUBLJENJA ISPOD POVRŠINE MORA.}

Vodene i podvodne aktivnosti nisu uvek bile privlačno vodeno iskustvo. Bilo je slučajeva kada su ljudi patili, bili mučeni ili su okončali svoje živote ispod površine mora. Pored slučajeva slučajnog davljenja, more je postalo grob ubica, pobunjenika, bezbožnika, ali i žrtava pirata.

U radu smo pokušali da rasvetlimo slučajeve kada je davljenje bilo korišćeno kao čin nasilja ili metod pogubljenja u antičkoj Grčkoj i drugo, da otvori prostor za dalje proučavanje i istraživanje podataka koji su ostali nerazjašnjeni.

Arheologija i prirodne nauke (Archaeology and Science) is an Open Access Journal. All articles can be downloaded free of charge and used in accordance with the licence Creative Commons - Attribution-NonCommercial-NoDerivs 3.0 Serbia (https://creativecommons.org/licenses/by- 
nc-nd/3.0/rs/.

Časopis Arheologija i prirodne nauke je dostupan u režimu otvorenog pristupa. Članci objavljeni $\mathrm{u}$ časopisu mogu se besplatno preuzeti sa sajta $\mathrm{i}$ koristiti u skladu sa licencom Creative Commons - Autorstvo-Nekomercijalno-Bez prerada 3.0 Srbija (https://creativecommons.org/licenses/bync-nd/3.0/rs/. 